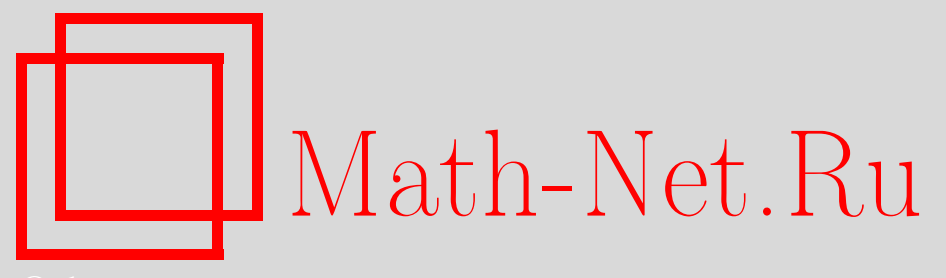

С. Дворянинов, Почему самолет взлетает против ветра, Квант, 2021, номер 1, 39-40

DOI: https://doi.org/10.4213/kvant20210103

Использование Общероссийского математического портала Math-Net.Ru подразумевает, что вы прочитали и согласны с пользовательским соглашением http://www.mathnet.ru/rus/agreement

Параметры загрузки:

IP: 3.82 .47 .9

26 апреля 2023 г., $14: 31: 47$






\section{Почему самолет взлетает против ветра}

\section{С.ДВОРЯНИНОВ}

- Я вижу, ты о чем-то крепко задумался? - спросил Папа Карло своего Буратино, заметив, что тот уже долго листает страницы учебника физики.

- Да, сегодня на уроке учитель сказал, что самолету легче взлетать против ветра. А нам надо объяснить, почему это так. Я весь учебник просмотрел, а ответа не нашел.

- Что ж, давай будем рассуждать логически, - Папа Карло отряхнул стружки с фартука, отошел от верстака и присел у стола.

- А как это - «рассуждать логически»? Логика - это когда из $A$ следует $B$. А в этой физической задаче никаких $A$ и $B$ нет, разочарованно произнес Буратино.

DOI: https://doi.org/10.4213/kvant20210103
- Ты не прав, - возразил Папа Карло. И сейчас сам в этом убедишься. Чтобы ответить на вопрос твоего учителя, мы выстроим логическую цепочку. Я буду задавать тебе вопросы, а ты будешь на них отвечать. Итак, начали. - Что происходит с самолетом, прежде чем он отрывается от земли и оказывается в воздухе?

- Самолет разгоняется, двигаясь по взлетной полосе, это ясно, - ответил Буратино.

- А относительно чего движется самолет?

- Относительно земли, конечно, и относительно того, что на ней находится. Это, например, здание аэровокзала, люди, которые, наблюдают за самолетами, деревья...

- Ну а самое главное-то что? Относительно чего движется самолет? Самолет разгоняется относительно воздуха! Будем вначале считать, что стоит безветренная погода, полный штиль, такой, что ни один листочек на дереве не шелохнется. Так вот относительно этого неподвижного воздуха самолет по взлетной полосе движется все быстрее и быстрее. Согласен? - уточнил Папа Карло.

- Да, согласен, это похоже на ускоренное движение моторной лодки по озеру. В

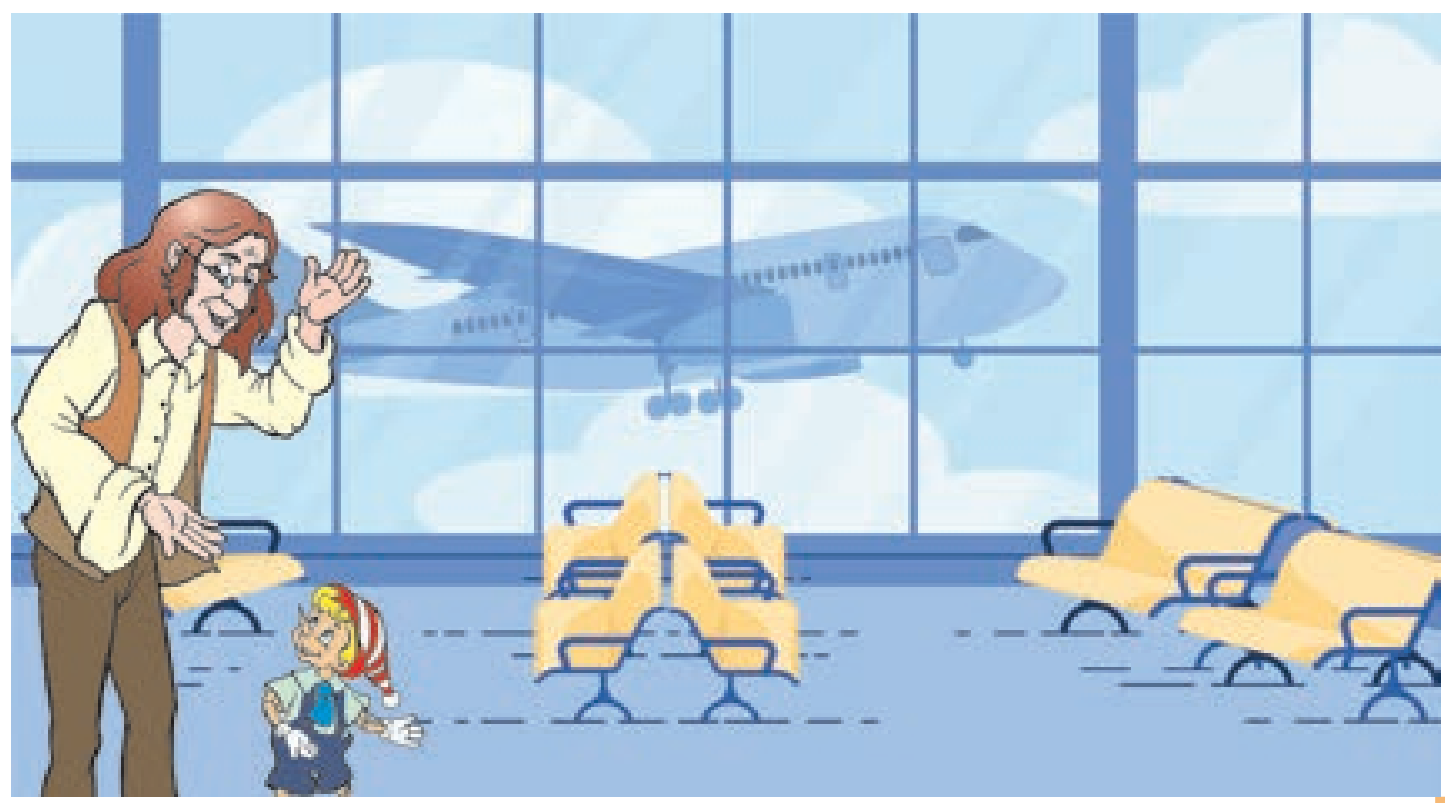


озере никакого течения нет, вода стоит неподвижно, - откликнулся Буратино. Как корабль плавает в океане, так и самолет плавает в воздушном океане.

- Не ошибайся в терминах, мой дорогой Буратино. Корабли не плавают, а ходят, так говорят настоящие мореходы-моряки. Плавают в воздушном океане, согласно закону Архимеда, воздушные шары, аэростаты, дирижабли да еще детские шарики, наполненные гелием. А самолеты летают. Но сначала они должны взлететь. И отрывает их от земли и поднимает вверх сила, которая называется подъемной. Она возникает, когда воздушный поток набегает на самолет, - продолжил Папа Карло.

- А вот когда я еду на велосипеде, я этот поток набегающий чувствую даже очень хорошо. Но при этом я вверх не поднимаюсь. И даже автомобиль, набравший большую, скорость, продолжает катиться по земле и никуда не улетает, - возразил Буратино.

- Верно ты все говоришь. Но самолет и особенно его крылья имеют такую специальную форму, которая приводит к появлению подъемной силы, направленной вверх. Чем больше скорость набегающего потока, тем больше становится подъемная сила. Наконец, она превосходит силу тяжести, действующую на самолет, и тогда воздушное судно отрывается от земли.

- Но если подъемная сила больше силы тяжести, то самолет будет подниматься вверх все выше и выше неограниченно. А так не бывает, - снова пытался спорить Буратино.

- Нет, конечно. Когда надо, пилот самолета, изменяя угол атаки крыла, добивается того, что две силы - подъемная и тяжести - становятся равными, и тогда самолет летит на неизменной высоте, заключил Папа Карло. - А теперь сопоставь все факты, о которых мы сейчас говорили, и объясни, почему против ветра самолету взлететь легче.

- Да, я могу объяснить! - воскликнул Буратино, - вот она, логическая цепочка. Для подъема самолета требуется достаточ-

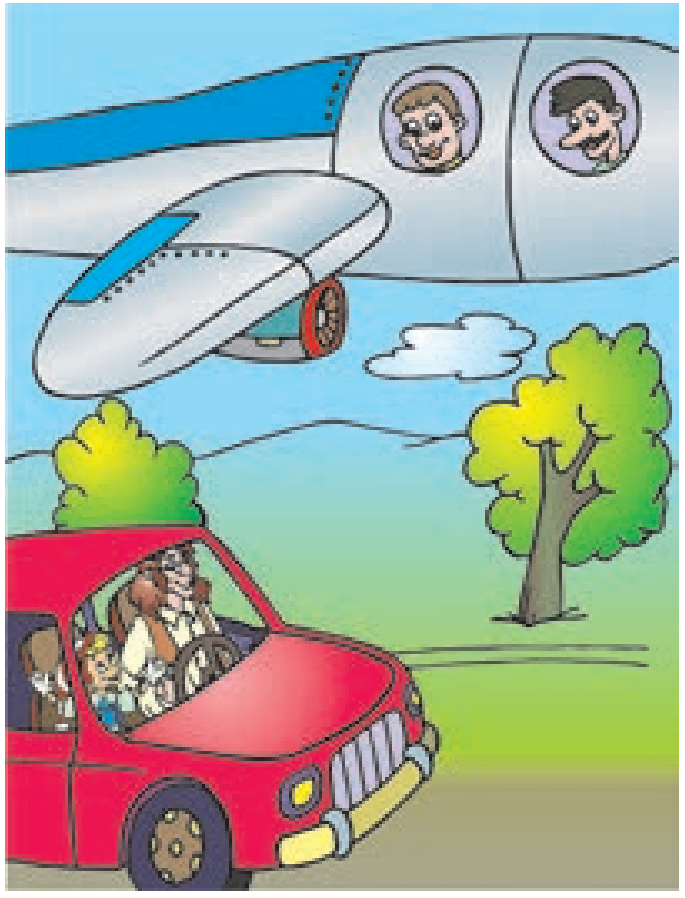

но большая скорость $v$ набегающего воздушного потока. Скорость - понятие относительное. Можно сказать, что поток набегает на самолет, а можно сказать, что самолет движется относительно воздушной массы. Когда на взлетной полосе ветер дует навстречу самолету, то скорость самолета относительно воздуха равна его собственной скорости плюс скорость ветра. При этом требуемое значение скорости $v$ получается при меньшей собственной скорости самолета. Вот так.

- Это правильно, молодец, - заключил Папа Карло. - Поэтому и говорят, что против ветра самолету взлетать легче. Это было особенно важно на заре авиации, когда двигатели были не очень мощные. Современные же самолеты могут взлетать и при попутном ветре, но в любом случае пилоты учитывают и скорость ветра, и его направление. Так что, вырастешь - станешь пилотом и вспомнишь сегодняшний разговор! А мне надо продолжать работу.

И Папа Карло направился к своему верстаку. 